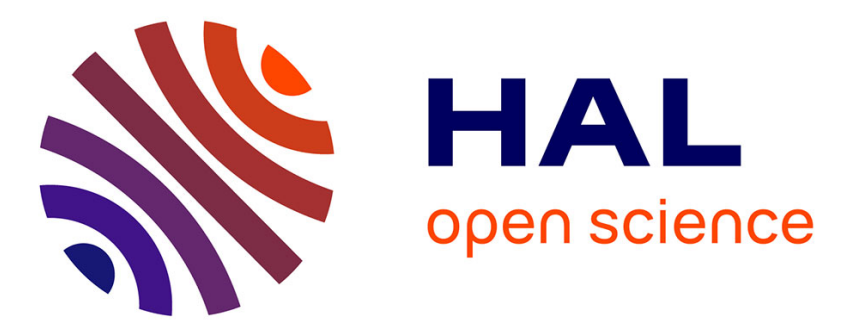

\title{
Electoral competition and gender quotas: dearth of female applicants or structural resistance?
}

\author{
Annabelle Caprais, Fabien Sabatier, Stéphanie Rubi
}

\section{To cite this version:}

Annabelle Caprais, Fabien Sabatier, Stéphanie Rubi. Electoral competition and gender quotas: dearth of female applicants or structural resistance?. International Journal of Sport Policy and Politics, 2020, pp.349-364. 10.1080/19406940.2020.1782966 . hal-02931365

\section{HAL Id: hal-02931365 https://hal.science/hal-02931365}

Submitted on 3 Nov 2021

HAL is a multi-disciplinary open access archive for the deposit and dissemination of scientific research documents, whether they are published or not. The documents may come from teaching and research institutions in France or abroad, or from public or private research centers.
L'archive ouverte pluridisciplinaire HAL, est destinée au dépôt et à la diffusion de documents scientifiques de niveau recherche, publiés ou non, émanant des établissements d'enseignement et de recherche français ou étrangers, des laboratoires publics ou privés. 


\section{Electoral competition and gender quotas: dearth of female applicants or structural resistance?}

\section{Annabelle Caprais , Fabien Sabatier \& Stéphanie Rubi}

To cite this article: Annabelle Caprais , Fabien Sabatier \& Stéphanie Rubi (2020): Electoral competition and gender quotas: dearth of female applicants or structural resistance?, International Journal of Sport Policy and Politics, DOI: 10.1080/19406940.2020.1782966

To link to this article: https://doi.org/10.1080/19406940.2020.1782966

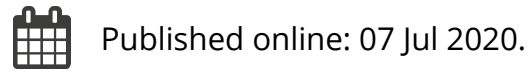

Submit your article to this journal $\square$

Q View related articles $\sqsubset$

View Crossmark data $₫$ 


\title{
Electoral competition and gender quotas: dearth of female applicants or structural resistance?
}

\author{
Annabelle Caprais ${ }^{\mathrm{a}}$, Fabien Sabatier ${ }^{\mathrm{a}}$ and Stéphanie Rubi ${ }^{\mathrm{b}}$ \\ aDepartement of human sciences, University of Bordeaux, Bordeaux, France; bepartement of human sciences, \\ University of Paris Descartes, Paris, France
}

\begin{abstract}
Gender equality has been a major discussion item on the French Ministry of Sports' agenda in recent years. In terms of governance, in 2014, the law $\mathrm{n}^{\circ} 2014-873$ 'for true equality between women and men' introduced two types of gender quota on the executive boards of national sports federations (NSFs). Senators and deputies relaxed the conditions regarding the implementation of quotas, alluding to a lack of female candidates. The present study investigates the claim that there are not enough female sports leaders and analyses the electoral competition in the governing bodies of French NSFs following the enactment of these quotas. The study adopts a mixed method, consisting of a quantitative study conducted on 107 NSFs and a qualitative investigation conducted on one Olympic federation in particular. Chi-square goodness-of-fit tests were used to assess whether women were under-represented on executive boards. In addition, we conducted seventeen semi-structured interviews. Overall, electoral competition for most executive boards appears to be very limited as most of the candidates were elected. Quantitative figures suggest that there is no voting bias against women and that it is rare for there to be a lack of female candidates. However, both visible and invisible resistance does exist. Some federations limit the application of the law through ex-officio members and consider quotas as a maximum. Moreover, backstage power strategies influence both the number of applications and the results of the ballots. Despite these factors, female representation in sport governance is rising significantly. After the last elections, it rose faster than it had in the previous decade.
\end{abstract}

\section{ARTICLE HISTORY}

Received 22 August 2019 Accepted 10 June 2020

\section{KEYWORDS}

Sport governance; gender quotas; women; national sports federations; elections

\section{Introduction}

The use of gender quotas is now widespread (Dahlerup and Gaber 2017) and France is no exception. In politics (e.g. legislative and local elections), company governing boards, public services, sports, and so on, quotas are flourishing and they generally share the same aim, namely, to increase female participation in decision-making. However, the outcomes of quotas on gender ratios vary (Dahlerup and Gaber 2017). In fact, the gender quota that applied to national sports federations (NSFs) until 2011 was revised in 2014 as it was considered to be merely symbolic and inappropriate. Indeed, the previous decree ${ }^{1}$ (called the "proportionality principle') linked the gender ratio of NSF governance to that of sports participants. Moreover, there were no sanctions in place for non-compliance.

When drafting the new regulation, the French government aimed to impose parity. However, legislators later decided to relax the legal application conditions as they assumed that the number of

CONTACT Annabelle Caprais annabelle.caprais@hotmail.fr 0 Departement of human sciences, Université de Bordeaux, 8 allée des Platanes 64100 Bayonne France 
female candidates would be insufficient to reach the 50/50 goal. To date, research on candidature issues in sports organisations remains underdeveloped, but there is no scientific evidence of a lack of female candidates at present. Nonetheless, the voluntary nature of board positions often leads to the assumption that women are responsible for their absence, while in fact other invisible and unexplored dynamics are at play (Claringbould and Knoppers 2007). Gender quotas are becoming a common response to low gender ratios, but they also represent a threat to male members' positions and may encourage men to develop resistance strategies. These aspects have not received much scholarly attention to date. Quantitative and qualitative investigations could thus help us to understand the dynamics of executive boards in voluntary organisations in other countries.

As well as assessing how quotas contribute to shaping the gender ratio of boards, this study also attempts to analyse the electoral process and backstage manoeuvring that takes place before elections.

In this context, we focus on two aspects: the results of the 2016-2017 elections and the recruitment of board members. First, we investigate the pipeline of candidates, examining the possible existence of voting bias and the claim of a dearth of female applicants. Second, we investigate the pre-election negotiations between the actors in an Olympic federation (Crozier and Friedberg 1977).

\section{Context}

France has a club-based system in which NSFs play a central role. 111 NSFs organise sport at both top and mass participation levels. They also award titles and manage talent identification. NSFs are membershipbased, nationwide organisations governed by volunteers. ${ }^{2}$ Although each federation has the freedom to determine its representation system, most of them operate under a similar delegate scheme. The structure is pyramidal: local and regional representatives form the general assembly and elect national representatives for the national executive boards, the highest decision-making level in NSFs. No written selection criteria apply to these top positions, except that candidates must have been members of the organisation for at least six months (as a local leader, volunteer, sports participant, coach ... ).

Some common principles, as set out in the Sports Code, have been formulated to ensure a democratic process and to regulate the renewal of the governing bodies. National leaders, who represent and act on behalf of the federation members, must be elected, and elections must be held every four years, within six months after the Olympic Games during the NSF's annual general assembly. During the 2017 elections, following the Rio Olympic Games, NSFs had to apply gender quotas. There were two types of scenario. NSFs with under $25 \%$ of men (or women) among the sports participants had to ensure that at least $25 \%$ percent of the seats of their governance body were assigned to women (or men). NSFs with more than $25 \%$ of both men and women among sports participants had to ensure at least $40 \%$ percent of the seats for men and women. However, for this second category, a transition period applies and NSFs can apply the proportionality principle.

\section{Recruitment processes in sports governance}

Research has provided a large amount of quantitative data on gender diversity in sports governance. ${ }^{3}$ A recent statistics-based meta-analysis by Elling et al. (2019) presented a comprehensive compilation of this work, showing that women are still underrepresented on many Olympic NSF boards in Europe. At international level, Schoch and Clausen (2019) came to a similar conclusion after highlighting the lack of women in both president and director positions in NSFs. The persistence of the skewed ratio led national and international organisations to acknowledge the issue. The European Commission committed itself to eliminating the gender gap in decision-making in European sport organisations (EIGE 2015). Similarly, the IOC, which began to address the issue in 1996 by implementing gender targets, has now set itself the objective of equal male and female representation by 2024. With this in mind, it drew up plans to extend the influx of potential female candidates (IOC, 2018). 
Indeed, now that gender targets and quotas have been introduced (e.g. in Norway, Sweden, Spain, Olympic bodies, some $\mathrm{ISFs}^{4}$ ), increased attention is being devoted to female 'potentials', with a growing number of leadership courses, coaching and mentoring programmes designed to encourage vocations (IPC, 2010, FIFA, 2015, UEFA 2018). Such strategies do not change organisational practices, but rather reflect the 'individual track discourse' "or 'fix the women not the system approach' (Hovden et al. 2019).

However, many researchers have highlighted the impact of gender in the selection process of leaders (Hovden 2000, 2012, Claringbould and Knoppers 2007) as well as in dropout processes (Pfister and Radtke 2006), helping to explain gender-skewed ratios. In the Netherlands, sports leader recruitment processes follow a 'gendered fit' (Claringbould and Knoppers 2007). Due to insidious gender discrimination, women try to negotiate their entry onto the board by distancing themselves from their gender and engaging in behaviours associated with men. Thus, Claringbould and Knoppers (2012) observed that the selection process is considered as neutral and fair (gender neutrality), inequalities are perceived as normal (gender normalcy), and board members fail to address the issue (gender passivity), while they use male networks as a privileged means to fill unoccupied seats. More broadly, Hoye and Cuskelly (2004) found that the recruitment of leaders was sometimes based on popularity rather than meritocracy or board performance in volunteer sports organisations.

Similarly, the doctoral research of Chimot (2005) on female leaders in French sports organisations revealed that behind elections, organisational practices often reveal a transmission of positions with leaders choosing their successors through their own networks. Like Elling et al. (2019), Chimot also highlighted the fact that the majority of opportunities for women occur in NFSs with a high share of female members and in less prestigious sport organisations (e.g. multisport NFSs). (S)elected candidates are primarily from medium/high social classes, have higher academic degrees and are younger than men (Chimot 2005). Consistent with these findings, Enjolras and Waldahl (2010) found that Norwegian Olympic Committee leaders differ socially from the mass of members they represent. This type of elitist governance seems to be inherently linked to the history of representative democracy. The system was deliberately introduced in the knowledge that it would distinguish certain citizens (Manin 1997).

The French sports domain, like many others in the world, relies on a pyramidal not-for-profit system that has seen a persistent skewed ratio in its governance. France, along with a few other countries, has implemented a 'hard law', namely gender quotas (and not only targets) in order to address the issue. In analysing organisations' strategies and circumvention schemes, this paper presents ways to adapt and develop better policies in the future, both in France and elsewhere.

\section{On the concept of power}

Our analysis of recruitment processes in NSFs are informed by the concept of power elaborated by Crozier and Friedberg (1977). Crozier and Friedberg are organisational theorists who focus on individuals' (also called 'actors') collective activities and power strategies. They do not consider power as an attribute, something possessed, but rather as a relationship. Power is located within interactions and is derived from four sources: (a) mastery of expert knowledge, (b) control of information and communication resources, (c) relations with the organisational environment and (d) control of organisational rules. In a nutshell, the ability to control a so-called 'zone of uncertainty' that may be vital for other stakeholders represents a source of power.

Actors are 'strategic' in that they have intentions and objectives. They are rational social agents that behave in a calculating manner (whether consciously or not) when making decisions and pursuing their best interests. In so doing, actors need to collaborate, negotiate and engage in a relationship of reciprocal exchange. Indeed, in order to achieve their personal objectives (e.g fame, prestige, profit ... ), actors need to participate in the organisation's activities and therefore 
interact with others. Within an organisation, actors' objectives may be unclear, incoherent and mostly conflictual (e.g. one board seat for two people).

Individuals' strategies are framed by the formal structure: 'within an organisation, each party tries to manipulate this relationship by using what mastery it has over the sources of uncertainty affecting the other party's behaviour, at the same time respecting the commonly accepted rules and objectives' (Crozier 1973, p. 226). Interactions produce what Crozier and Friedberg call a 'system' that may transcend the organisational structure. For instance, holding multiple positions in different structures and multiplying interactions with stakeholders tend to blur the boundaries of organisations. In this sense, NSFs have a broad contacts network (e.g. clubs, Sports Ministry, Olympic organisations, International Federations, other NSFs ... ), providing great opportunities for social interactions and information exchange.

Alliances between actors may increase their freedom, but as transactions, they also require minimal compensation. Thus, their very nature makes power relationships unbalanced. Exchanging action-related options always champions one of the actors, in other words, one of them will gain more than the others. Herein lies the interest of the model as it aims to analyse how actors, who are mutually dependant, but also potential rivals, cooperate and stabilise their alliances in organisations. It thus offers a new way of examining power relations in NSFs and analyses how individuals resist and adapt to regulations (i.e. gender quotas).

Discussing the issue of power is often taboo in French NSFs as such non-profit entities generally value a form of conviviality and friendship between the stakeholders. As representatives of the members, leaders are supposed to serve the sport's development in an impartial and altruistic way, in line with the ethos of volunteering. Thus, while the expression of personal ambition is valued and widespread for most athletes, showing concern for one's own personal career may be seen as indecent for volunteer leaders. However, this does not mean that there are no power issues (Crozier 1973). Rather, it confirms that sports leaders are 'theatre actors' as described by Goffman (1959), as they present themselves as disinterested and altruistic individuals.

In this framework, we consider NSFs as conglomerates of actors with antagonistic personal objectives that aim to maximise their interests (Bernardeau Moreau 2004). Even if we cannot determine the actors' objectives a priori, we can at least assume that candidates for the executive board want to be elected and that they develop winning or losing strategies to this end. After analysing some quantitative figures about applications, we will focus on these specific strategies together with formal and informal negotiations that occurred before the 2017 elections in one NSF.

\section{Multi-method research approach}

This study is twofold. First, we investigate the impact of gender quotas and we assess claims that women are under-represented among candidates and that they have a lower success rate than men. We then concentrate on one specific NSF and analyse its application procedure.

\section{Quantitative part}

\section{Sample and data collection}

On the quantitative side, we analysed 107 of the 111 NSFs with regard to the 2017 elections. When possible, we collected data about the gender composition of the governance, the statutes and official reports from the federation's website. When the information was not online, we asked for it by email or over the phone. After a good deal of contact, we gathered 87 official electoral reports related to the 2016-2017 elections (35/36 Olympic, 36/50 non-Olympic unisport and 16/21 multisport) and 27 official electoral reports related to the 2012-2013 elections (27/36 Olympic). Aggregated data related to the gender composition of the previous Olympiads comes from the Ministry's database. 


\section{Data analysis}

The whole set of quantitative data was compiled and coded in a file. A chi-square goodness-of-fit test was then used to assess discrepancies between theoretical expected gender ratios and observed ratios for each federation and overall. We computed the data using the online software www. socscistatistics.com. Our aim was to assess whether:

- Sports federations respect gender quotas;

- Men and women are under or over-represented among board members compared to the gender ratio of candidates.

We computed the theoretical distributions in accordance with the provisions of the law, rounded to the nearest integer for the less represented gender in sports participation. The elections took place in 2016-2017, so we used 2015 sports participant data in order to compute the theoretical distributions. The threshold of significance was set at $p<.05$. In addition, the effect size $(w)$ was calculated to determine the size of the significance. According to Cohen (1992), results of $0.1,0.3$ and 0.5 represent small, medium and large effect sizes, respectively.

\section{Qualitative part}

\section{Sample and data collection}

For the case study, the federation's selection was based on the gender ratio of the sport discipline, its willingness to respect the law and availability to take part in the study, and the popularity of the sport. We decided to investigate the recruitment process of an Olympic ${ }^{5}$ NSF as the power struggles between leaders are often fiercer than in other situations. This is because Olympic federations are the most prestigious, with considerable economic weight, attracting the attention of media and fans like no other. The fact that Paris will host the Olympic Games in 2024 not only bolsters their dominant position in the social and political landscape, but may also strengthen the leaders' determination to stay in office.

The federation is in charge of a team sport discipline. The gender ratio of sport participants is balanced, and the number of sports participants increases every year. We decided to focus on a specific federation for two reasons. First, the NSF respects the law regarding the governance gender ratio, but had decided to apply the proportionality principle ${ }^{6}$ instead of implementing the $40 \%$ quota. Thus, female leaders had 13 seats reserved on the executive board instead of 15 . However, electoral experience showed that there were enough female applications to reach the quota. In 2008, two women received more votes than men, but were not elected due to the proportionality principle. Thus, the federation seemed to have a female participation problem for the 2017 elections. Only three female candidates were not elected (13 men).

We sent emails and made phone calls to the current executive board members and non-elected candidates to invite them to take part in the study. Thus, seventeen semi-structured interviews were conducted (10 women, 7 men). The interviews were held face to face or over the phone. Before each interview, we informed the participants of the aim of the research and asked them if we could record the conversation. All of them gave their consent. The interviews lasted 74 minutes on average. Three of the participants ( 2 women, 1 man) were newly elected and had joined the board under the quota regulation. One female participant had previously been a board member but was not re-elected. The others had been board members for more than one mandate (4 years). Two of them (one man, one woman) had already lost a national election in the past. The interviews were carried out using an interview guide informed by the elements stemming from the theoretical approach and the research question. The participants were questioned about:

- their personal goals (i.e. the reasons why they initially decided to take on the responsibility and why they keep doing it); 
- their strategies and sources of power (i.e. how they prepared for the elections, whether they hold multiple mandates, their career evolution in the organisation);

- their degree of interdependence with others (i.e. their relationship with other board members).

\section{Data analysis}

All of the interviews were transcribed. We then analysed the respondents' discourse using open coding with Nvivo software. In view of the key notions of the theoretical framework and following an inductive approach, we searched the data for emerging themes. Following this preliminary coding, segments of the corpus were grouped into categories. Categories included a description of the location where the board members were identified and recruited, the recruiters that contacted them, their strengths and weaknesses (e.g. reputation, awareness (or lack of) of the regulations, voting power, electoral weight) and the way they were (not) elected. In sum, we tried to paint a portrait of each actor to determine their personal motivations and objectives (e.g. social prestige), sources of power (e.g. reputation, holding multiple mandates) and strategies (e.g. alliances with other actors).

\section{Limitations}

There are several limitations to the study. The first is linked to the fact that official electoral reports only state the first and last name of candidates. As we did not have access to candidates' sociological and demographical data, we could not adopt an intersectional perspective. Nonetheless, without being precise, it appears that white males occupy most of the board seats. In the same way, we could not measure incumbency advantage, perceptions of likeability, competence and hence, control variables related to voting bias. Thus, the success rate of candidates is used as a cue for voting bias.

Finally, the case study reflects just one particular situation in more than a hundred. Given that each NSF has its own specific features (e.g. economic power, representation and voting rules) and that the type of federation as well as the governance structure may influence power strategies, our results cannot be generalised to other NSFs.

\section{Results}

This section is fourfold. The first and the second parts present the quantitative findings, namely, the impact of quotas on women's representation on executive boards and the gender ratio of candidatures, while the third and the fourth parts are dedicated to structural resistance in NSFs.

\section{Quotas as a fast track}

As observed in recent years, the number of women on NSF boards has been steadily growing (Figure 1), increasing faster than on IF boards (Schoch and Clausen 2019) and feminisation appears to have sped up thanks to quotas. Indeed, the percentage of female board members increased between 2013 and 2017, whereas it stagnated between 2009 and 2013. . For the 2017-2020 period, women's representation in governance (34.5\%) and sport (38\%) are almost equal. Most of the NSFs do not achieve either critical mass or gender balance, but the percentage of women board members in France remains higher, on average, than in other European countries (Adriaanse 2019).

Beyond the aggregate data, a case-by-case analysis reveals that most NSFs respect gender quotas, showing a 'threshold effect' that strictly respects the number of seats reserved for women. Among the 35 federations that feature over $75 \%$ of male sports participants and respect the law, 27 reached the threshold of $25 \%$ of women on their board exactly. Thus, for some federations, gender quotas, which in theory correspond to a minimum, are the norm. These findings are consistent with those of Rich et al. (2004), who showed that IOC targets have sometimes been implemented by NOCs as 'a ceiling to be attained rather than a base from which to build' (2004, p. 89). 


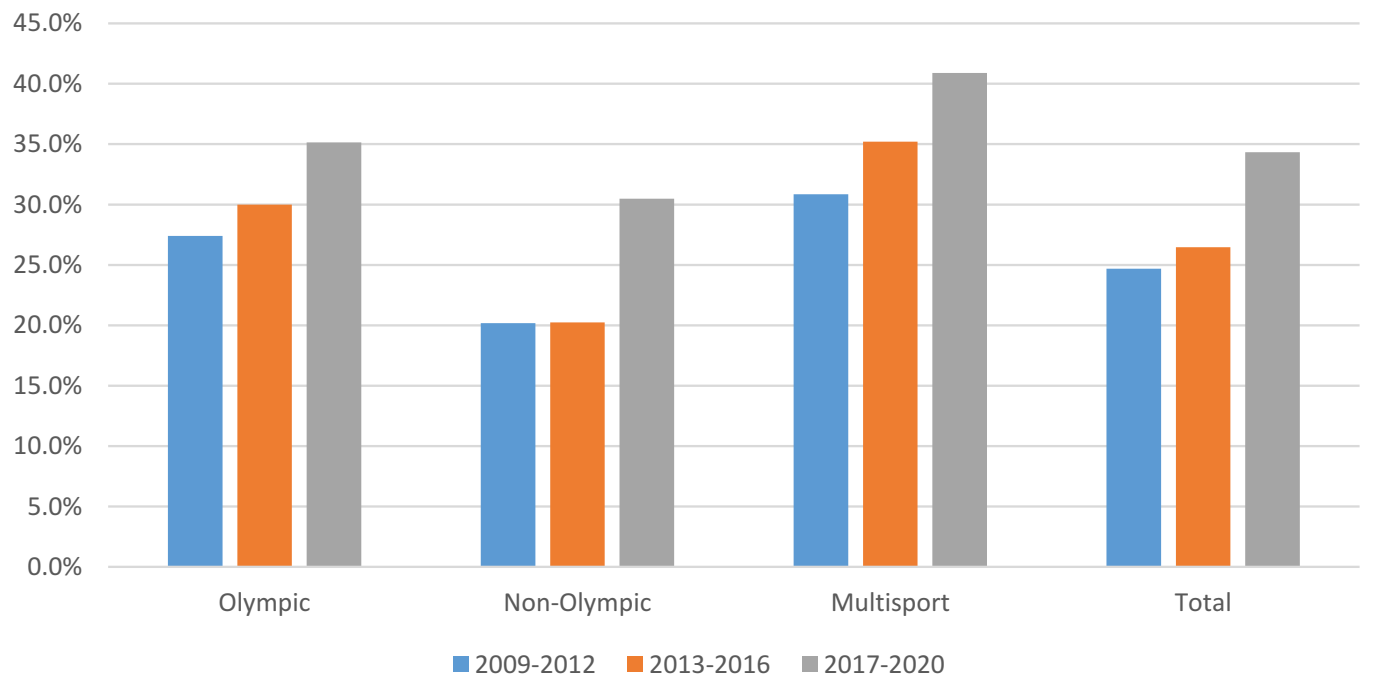

Figure 1. Diachronic analysis of the share of women on NSF executive boards according to the type of federation (2009-2020).

Is this 'threshold effect' an act of resistance by sports federations, or is it proof that sports organisations have trouble recruiting female sport leaders? In order to shed light on this issue, we investigated the 2017 elections applications. The data suggest that both lack of female candidates and formal and informal resistance by actors are mainly responsible for the 'threshold effect'.

\section{Electoral competition and voter bias}

Fewer female (33.2\%) than male candidates join the electoral arena (Table 1). However, the claim that there are not enough female applicants to fulfil the quota needs to be qualified. The results revealed contrasting situations. Some NSFs have more female candidates than reserved seats. For instance, in the swimming federation, there were 25 female candidates for 13 reserved seats. In addition, for mixed systems, female candidatures are sometimes poorly distributed between the two ballots. The efficiency of gender quotas relies, in part, on electoral processes. To be precise, the combination of different voting systems and ex-officio members appears detrimental to the respect of gender quotas.

Moreover, contrary to the government's predictions, the lack of applications concerns both men and women. While, in four NSFs, there was a lack of one or two female candidates to fill the quota, in one federation two male seats remained vacant due to the lack of candidatures. The aggregated data shows that the overall electoral competition is very limited. This is particularly true in list systems where competition is almost non-existent. On average, only 1.4 lists were registered per federation, and for 32 federations, only one electoral list was competing. Once the candidatures are filed in the electoral race, very few candidates are disappointed. As proof, $87.1 \%$ and $71.9 \%$ of female and male candidates for multisport federations were elected. Competition is naturally stiffer in the most prestigious Olympic federations. The average success rate of tennis, soccer, basketball and rugby federation candidates is only $38 \%$.

Table 1. Gender ratio of candidates and elected members according to the type of federation.

\begin{tabular}{|c|c|c|c|c|c|c|c|c|}
\hline & \multicolumn{2}{|c|}{ Olympic (35) } & \multicolumn{2}{|c|}{ Unisport (36) } & \multicolumn{2}{|c|}{ Multisport (16) } & \multicolumn{2}{|c|}{ Total (87) } \\
\hline & Women & Men & Women & Men & Women & Men & Women & Men \\
\hline Share of candidates & $34.9 \%$ & $65.1 \%$ & $28.9 \%$ & $71.1 \%$ & $37.4 \%$ & $62.6 \%$ & $33.2 \%$ & $66.8 \%$ \\
\hline Success rate & $68.1 \%$ & $65.4 \%$ & $82.3 \%$ & $76.6 \%$ & $87.1 \%$ & $71.9 \%$ & $75.6 \%$ & $70.5 \%$ \\
\hline Share of elected members & $35.8 \%$ & $64.2 \%$ & $30.3 \%$ & $69.7 \%$ & $42.1 \%$ & $57.9 \%$ & $34.7 \%$ & $65.3 \%$ \\
\hline
\end{tabular}


Contrary to Guichet's (2015) observations, the results show that, whatever the type of federation, elections seem to favour women who always outperform men. In multisport federations, for example, women represented $37.5 \%$ of candidates and $42.1 \%$ of elected members. Thus, voting does not seem to affect the representation of women who are better represented than men among elected members compared to their share of candidates, but they are not over-represented (Table 2).

Moreover, this gender gap seems to be getting smaller. Indeed, the share of female candidates in Olympic federations ${ }^{8}$ grew by 7.1 compared to the 2013 elections, whereas the share of elected women increased by 5.9, resulting in a lower success rate compared to 2013 (Table 3).

The lack of female candidates explains, on the one hand, the under-representation of women in sport governance, but it is not the only explanatory factor. Structural resistance also contributes to the 'threshold effect'.

\section{Ex-officio members}

Some formal limitations in the statutes of organisations have limited women's access to governing bodies. Sometimes gender quotas are viewed as a maximum, so once the seats reserved for women have been allocated, no more women can be elected. For instance, one NSF limited the number of female seats by applying the proportionality principle instead of the $40 \%$ quota, even though experience showed that there were enough female applications to reach the quota.

In the same way, some NSFs do not elect the entire executive board and reserve seats for exofficio members. For instance, the Judo federation executive board is composed of 33 members split into two governing bodies: the executive board and the national council. The executive board is composed of 17 elected members drawn from a list system. The national council is composed of 16 members representing regional territories that are not elected (i.e. presidents of regional committees). The federation decided to continue to have a percentage of women at least equal to the share of women among the sports participants (i.e. $26 \%$ in 2015). Thus, five women were elected to the executive board (29\%). However, there are no women on the national council. Consequently, among the 33 members that form the governance body, women only represent $15 \%$ of the seats instead of the $26 \%$ required by the Sports Code.

There is then a structural effect, in other words, part of the composition of the governance body is predetermined. The regional imbalance breeds the national imbalance. Some federations fail to

Table 2. Gender ratio of elected members compared to gender ratio of applications according to federation type.

\begin{tabular}{|c|c|c|c|c|c|c|}
\hline & Women & Men & Total & $\mathrm{X} 2$ & $\mathrm{P}$-value & w \\
\hline \multicolumn{7}{|l|}{ Olympic (35) } \\
\hline Elected members & 370 & 663 & 1033 & 0.426 & 0.514 & 0.020 \\
\hline$\Delta$ & 10 & -10 & & & & \\
\hline \multicolumn{7}{|l|}{ Non-Olympic (36) } \\
\hline Elected members & 256 & 588 & 844 & 0.977 & 0.323 & 0.034 \\
\hline$\Delta$ & 13 & -13 & & & & \\
\hline \multicolumn{7}{|l|}{ Multisport (16) } \\
\hline Elected members & 149 & 205 & 354 & 3.083 & 0.079 & 0.093 \\
\hline$\Delta$ & 16 & -16 & & & & \\
\hline \multicolumn{7}{|l|}{ Total (87) } \\
\hline Elected members & 775 & 1456 & 2231 & 2.477 & 0.115 & 0.033 \\
\hline$\Delta$ & 35 & -35 & & & & \\
\hline
\end{tabular}

Table 3. Share of female candidates and elected members of 27 Olympic federations for the 2013 and 2017 elections.

\begin{tabular}{lcc}
\hline Olympic federations (27) & 2013 & 2017 \\
\hline Share of candidates & $27.0 \%$ & $34.1 \%$ \\
Sucess rate & $71.6 \%$ & $67.9 \%$ \\
Share of board members & $29.3 \%$ & $35.2 \%$ \\
\hline
\end{tabular}


apply the law that stipulates that 'governing bodies' and not 'elected members' are subject to the quota regulations. This limits new members' ability to join and favours incumbents, even though it is prohibited by the Sport Code: 'The members of governing bodies are elected by a secret vote for a period of four years. ${ }^{9}$ Ex-officio members are allowed in ordinary associations, but not in NSFs. However, as noted, the automatic inclusion of presidents of regional committees and/or professional leagues is widespread and is not considered an infringement of sports democracy.

In addition to these straightforward evasions of the law, we observed various degrees of voluntarism. Some federations increased the size of their governing bodies. Some did not hold new elections to replace female board members who had left. Others tried to negotiate with the Ministry in order to change the gender quota calculation.

\section{The selection procedure}

Additional interviews with the board members of an Olympic federation confirmed the importance and persistence of the 'presentation processes' (Chimot 2005) that take place before election day. We first describe the election system of this NSF and then present the three different stages (i.e. identification, validation and voting instruction phases) that make up the recruitment process of this NSF.

\section{The representation system}

Local and regional representatives (also called the general assembly), previously elected by club presidents, elect the executive board of the umbrella organisation. Elections are plurinominal and the electoral weight of voters varies according to the number of members they represent. Regions with the most sports participants hold the largest shares of votes. The executive board is the legislative organ of the NSF and decides on the formal regulations. Meetings are held four times a year on average.

On the same day, the newly elected executive board selects a chairperson from among its members, who must then be approved by a general assembly vote. Finally, in the following weeks, the executive board elects the federal committee composed of 14 members, including the chairperson, the vice-presidents, the general secretary and the treasurer. The federal office is the most prestigious political organ of the NSF. Its members have more responsibility than executive board members, and they draw up the general NSF policy. They meet once a month to supervise the work of sub-committees and the organisation's daily life. The federal office is entitled to take urgent decisions.

For the 2017 elections, fewer than 200 voters made up the general assembly, representing more than 4000 clubs. There were 51 candidates for 36 executive board positions. 13 women and 23 men were elected, almost all white. It is important to note that these elections are not comparable to political elections. Candidates are volunteers; most of them have few resources at their disposal and they develop small-scale electoral campaigns. As a result, elections took place in a relatively low information context. However, the candidates did not stand as equals before the voters. Indeed, some of them were also voters, as they were elected as regional or local representatives (i.e. they had relations with the organisational environment). They thus had a source of power as defined by Crozier and Friedberg (1977) as they were able to negotiate and create strategic alliances and could exchange their votes. Moreover, representatives of the two largest regions (31 in total) represented $25 \%$ of the votes. The outgoing president enjoyed the most privileged position. He could communicate more easily than the other candidates, was the only one with a full-time job at the federation and had organisation resources (e.g. the ability to set up meetings, travelling expenses ...) at his disposal in order to campaign. While voters received the candidates' manifestos and biographical information, the candidates did not get an opportunity to present their programme on the day of the election - apart from the president who used some of his 
speaking time to talk about his wish to stay in office (i.e. control of information and communication).

\title{
The informal recruitment process
}

\section{Detection}

Pre-election processes go through a 'detection phase' where incumbents approach potential board members. This detection of newcomers mirrors the equal chances rhetoric (Elling et al. 2019) but is not based on formal rules and occurs under the supervision of the president. In fact, all of the interviewees described the role of the president and insiders in their appointment. This first contact usually takes place inside the organisation (e.g. in training sessions, sub-committees). Eva, a female board member, described how she decided to take up national responsibility:

\footnotetext{
They held a summer university. I was there and I was detected just like that, by a man who was in charge of the training commission and he was also president of the club of $B$, during the finest hours of $B$, and he was a member of the federation. And so, he began to get me started on this, he told me: "you have to come to the federation, etc." I said "me, I've never been a high-level athlete, I've just done sport." "Well, you have some skill as a sports leader", and like that I got involved in the federation. I wrote a letter because he pushed me a lot ... and he sent a letter to the president saying, "this one, we must ...". So, I started like that and was elected without any trouble. I've been on the executive board for 12 years now, 13 years soon (...). Really, the summer university for Young Sport Leaders pushed me, that's certain because some of us stood out from the crowd and then the right people asked the right people and they voted for me. (Eva, board member)
}

Not all board members are entitled or feel legitimate enough to propose newcomers. The president only allows some of them to do this. Carole, the only woman to say that she had selected newcomers is one of the vice-presidents. In conducting her 'recruitment', she expressed solidarity with other women. At national level, she asked three of them to join the board and she 'transmitted' her position as president to a woman at regional level. She selected women because she felt they would match the profile:

\begin{abstract}
Among newly elected women, three of them are members of my youth commission (laughs) and they are women, so I asked them to come and run for the federation's executive board. They're young; they want to participate because it's part of the next cycle. Only three women were president of regional committees, Corsica, French Guiana and me. At the time, there was another woman, but never more than three. (...). Fortunately, I protected Patricia (laughs), I protected Patricia, if you like, Patricia she started with me on the youth commission.
\end{abstract}

\section{- How did this transition with Patricia happen?}

Simply, she started with me in 2008 , for four years she had the youth commission on the regional committee. In 2012, I asked her to become vice-president because, here again, I wanted women to be in senior positions, so vice-president of the regional committee (...). She was in the sports domain so she had a network, and in particular with the National association of elected officials in charge of sport. She had a great network, it's also very important. She's also very altruistic, so the perfect profile. (...). In any case, among the pool of people that I had in front of me, I thought she could take over. I felt like she was in the same vein. (Carole, vicepresident)

\section{Validation}

Thus, potential candidates have to get the agreement of both grassroots and top levels of the pyramid. The former authorise them to represent their interests, while the latter allow them to join the team. Thus, while elections are plurinominal and do not rely on a list system, candidates ask for the president's permission before running for office. More than a mentor/mentee relationship, we show evidence of the persistence of a 'patronage system' among board members. Anne, a female board member, describes the process: 
At this time, we were two candidates, so there was me and a former high-level female athlete. Given this athlete's professional background, and me being unknown in the federation world, I withdrew my application. Then I asked for a meeting with the president, and he kindly received me in Paris. We had a business lunch and I explained to him my project and my determination to work at the federation. Then, we got in touch at other times and he told me that he had validated my demand, my candidacy (...). (Anne, newly elected)

Rather than issues of competency, lack of recognition (being unknown) seems to be the main disadvantage. In this context, former high-level athletes, incumbents and presidents of large regional committees (who are mostly men) have an advantage. Lack of information, the organisation's apparent social links as well as vagueness regarding the issue of competence appears to favour insiders. However, 'being on the president's team' may balance out a candidate's relative anonymity. The following words of Laurent, a newly elected male board member, illustrates this point:

Being unknown had already happened to me. I was an unknown candidate 4 years ago. I come from a small regional committee with fewer than 5000 sports participants (...) so the lack of reputation could have prevented me from being elected. It was the case 4 years ago, but this time I knew more people and I was part of a team, so it was easier. (Laurent, newly elected)

\section{Vote instructions}

Regarding manifestos, applicants generally present themselves as 'serving the sport's cause'. However, this is only front of stage behaviour (Goffman 1959) as the participants' answers show that the volunteer ethos obscures conflicts of power. In the pre-election period, voters receive instructions and intimidation. Negotiations are often held by phone and are planned by experienced candidates. For instance, the president gave voting instructions using an informal 'blacklist' so as to elect as many members of his 'team' as possible (i.e. communication control). The success of this process was crucial to his own survival within the organisation; board members elect the president and another candidate and informal teams also covet the seats. Thus, even if an election is plurinominal, the notion of 'team' is omnipresent. Rules related to its leaders' 'career advancement' are arbitrary and rely on interpersonal ties.

Stella was recruited by the former president and was a board member for two terms. In 2017, she was informally ejected from the new president's team for the election. The reasons for her expulsion are not clear, but she assumes that it is because she used to express disagreement during meetings and that she may also have been in contact with the opposing team. Anyway, her presence on the board was no longer desirable for the new president:

He [the president] didn't call me and I heard through friends that he had written a list with the exact number of people and I wasn't part of it. At the same time, there was another blacklist with people that shouldn't be elected and I was on that list. I didn't read them but people call you and say "you know, Stella ..." but no one shows you. (...) After the election day, some people tell you "you know, he said that we shouldn't vote for you, but I voted for you because I know you." After, there are people that you don't know, that were on the list and they got elected. (...) We don't know them, we don't know what they want to do, they were never part of a committee, a regional committee, a project, and these people get elected. (Stella, former board member)

Thus, voting instructions are designed to boost certain candidates and to manipulate the most important electors. Eva, for instance, talks about how she lost the election a few years ago. According to her, the opposing team spread 'fake news' about her:

There were negotiations and at $11 \mathrm{pm}$, I got a phone call and someone told me, someone I know very well, we've been friends for a long time: "Eva, there's a message saying that you gave an order to remove P. committee from the ballot box. $P$. is a very big regional committee, it has a lot of impact. So, they wanted people to have a bad opinion of me. In fact, they were the only ones that voted for me. As a result, I wasn't elected. (Eva)

In the same vein, Carole, the current female vice-president, explained how she was elected onto the executive board for the first time. The federation needed more women on the board due to the 'proportionality principle', so the board influenced the vote and the candidates. 
In June 2007, there were three men and me competing, well, of course the message went around that ... so I was elected if you like.

So, they influenced the vote...

They don't influence, but when people came up to me, because they didn't know us at all ... men were better known than me and I was the unknown one, and I'd say, I was pulled out of the hat. Who is she? Where does she come from? What does she do? Well, the "youth commission" insiders, they knew me, well knew me .... They'd heard about me. After, you know, in the general assembly there are 600 people, and I worked for just one in my region, I hadn't worked outside it yet. So, as they needed a woman, they needed to feminise the federal office, the executive board. Well, they took me. (Carole, vice-president)

A male executive board member also recalls this event. He stepped aside and did not run for office after a request from the executive board (i.e. the validation stage):

The first time that I wanted to run for office, it was in 2006 in a partial election. If I had been a candidate ... there was maybe a woman, who is now vice-president in charge of youth, who wasn't sure she'd be elected because I was better known than her in the network, and there was a risk that she wouldn't be elected. So they gently asked me: "ah, maybe it would be good if you stepped aside so as to give her a chance." I said yes, yes, I'll step aside for a woman, it's not a problem. (Emmanuel, federal office member)

In other words, elections are not as open as they look like at first sight. Candidates have to pass through different 'checkpoints' in order to be elected. Given these barriers, uncertainty is quite limited for most of the incumbents; the day of the election is not as crucial as it seems. The biggest challenges take place in the pre-election period and rely on the ability to form alliances with the most important voters and actors. Opponents' teams may sometimes try to eject or overthrow the dominant team through informal manipulations and arrangements, but such shenanigans are often unsuccessful as incumbents are generally entrenched in board positions.

\section{Discussion}

Women's presence on the executive board of NSFs has grown faster in the past four years than over the last twenty years. Gender quotas seem to have played a positive role with regard to these results and may have led to a more favourable climate, greater incentive to vote for women and a larger number of female candidates. These observations differ from those of Sineau (2012) who noted that during the 2002 and 2007 legislative elections, the implementation of a parity law led to a rise in female candidates, but to a smaller increase in women elected. These discrepancies may be due to the fact that in politics, parity applies to candidatures, while in the sports domain, quotas apply to seats. In similar vein, reserved seats may help to explain the absence of voter bias. However, compared to corporate boards, progress remains slow. ${ }^{10}$ Indeed, despite general compliance, some resistance has weakened the impact of the law.

The findings show that gender representation issues are embedded in broader democratic issues. Ex-officio members reduce democratic participation as they are not elected in the same way as other board members; regional elections lead to compulsory national mandates. This situation is the result of previous power struggles. Presidents of regional committees impose their presence on the national board and gain personal advantages from this situation (e.g. access to information).

Why are women under-represented among ex-officio members? Because this privilege is that of presidents. As long as both ex-officio members and the glass ceiling problem exists, the gender ratio of the governance of most NSFs will remain unbalanced. NFSs are no exception; circumvention strategies exist wherever gender quotas apply. In politics, some parties prefer to pay fines rather than choose female candidates (Troupel 2013). Some firms have changed their status or reduced the size of the board in order to sidestep the law (Ahern and Dittmar 2012, Gresy 2016). Such resistance to the implementation of quotas can be described as the tactics of male incumbents to stay in power as quotas are a direct threat to their position. 
With respect to the pool of candidates, we observed low levels of participation. Several factors may help to explain this. Some sports disciplines are less well known and thus struggle to attract both participants and leaders (e.g. the air sports federation); organisational distance between the grassroots and the top of NSFs discourages volunteers (Enjolras and Waldahl 2010); board positions are time consuming and often require personal financial contributions; and organisational practices contribute to reducing participation. Concerning gender, the statistical analysis shows that the under-representation of women candidates helps to explain their under-representation in board positions. However, quantitative data alone gives an incomplete picture of the situation. Two factors may inform this gender gap. Women are less encouraged to enter the electoral arena and are less likely to view themselves as qualified to run for office (Fox and Lawless 2004).

In contrast to the latter proposition, beyond the numbers, we found that incumbents forged advancement opportunities by encouraging or discouraging certain candidates, using 'backstage' strategies to influence the election results. Thus, the candidates/elected member ratio, presented in this paper as the success rate indicator, is in fact flawed. Relatively similar to the 'party bias' observed in politics (Murray et al. 2012), a 'recruiter bias' distorts the count. Indeed, electoral success involves informal recruitment that take place before the vote is taken. Certain incumbents control the selection process and a significant 'zone of uncertainty' (Crozier and Friedberg 1977) as they are able to negotiate newcomers' admission to the board: 'The right people asked the right people and they voted for me'. The fact that they could be candidates and voters at the same time seems to comprise the most important source of power. Holding multiple positions increases the likelihood of alliances and ensures access to information and the ability to create political alliances with popular, likeable or powerful newcomers in order to preserve or reinforce their position. Thus, as Hoye and Cuskelly (2004) observed in Australian volunteer organisations, board selection is not always skillsoriented but aims to satisfy the interests of the most important decision-makers. Election arrangements are interwoven at the four different levels of the umbrella organisation (clubs, local, regional and national boards), creating a hidden 'labyrinth leadership' (Soler et al, 2019).

The results might conflict with other NSFs, since each federation has its specific governance and representation system. First, NSFs with list systems and applicants that postulate directly for presidential positions may go through less informal negotiations. In addition, the smaller the number of voters, the more unequal the distribution of votes between electors. Finally, lesser-known and less prestigious NSFs often have trouble finding candidates for board positions and this could reduce backstage power strategies.

Informal support from dominant actors ensures exposure, access to the flow of reserved information, protection thanks to voting instructions, and introductions to the 'right people' holding central positions on the 'president's team' (Bower 2009). However, while incumbents may buffer them from adverse forces, candidates may also contract a symbolic debt. Analysing the career of local female sports leaders, Tatu-Colasseau and Vieille Marchiset (2010) talked about a 'gift/counter-gift system' in which female newcomers cannot liberate themselves from the control and authority of their recruiter - frequently an older man. In sum, these informal selection practices partially recreate a form of hierarchical relationship where more experienced male incumbents in the upper echelons counsel and manage the female newcomers' career. Although there is little room for women to change such selection processes, some of them develop individual resistance strategies that disrupt these gender arrangements (Goffman 2002, Tatu-Colasseau and Vieille Marchiset 2010). For instance, a female vice-president is an agent of change, standing in solidarity with others and choosing to recruit and promote women only.

Two of the four sources of power described by Crozier and Friedberg (1977) play a major role in the selection process. Having internal political resources and controlling communication channels is crucial to electoral success. They facilitate collusion and arrangements between candidates and contribute to keeping out gender diversity. However, as the model assumes that actors always have a means to avoid domination (i.e. to act and resist), it accentuates the difficulty of accounting for sexism (and its interrelationship with racism, ageism, etc.) as a system of oppression. This does not 
mean that sexism is absent, but it is considered as a micro individual strategy developed by women and men in order to preserve their personal interests. Nonetheless, without questioning the issue of agency, we can note that organisational regulations do not apply uniformly to all actors (e.g. higher standards for non-white men) (Eliev and Bernier 2003) and that they indeed favour some of them.

In this sense, informal rules pertaining to access to power positions tend to favour homosocial reproduction, and continue to reflect a masculine version of leaders (Hovden 2000, Claringbould and Knoppers 2007, 2013). Criteria are thought to be meritocratic and gender neutral, but they remain detrimental to women and minorities. Matching the profile of top positions involves networking, connivance with those in powerful positions, holding multiple positions in the organisational structure (Soler et al. 2019), working long and unsociable hours (Piggott and Pike 2019) and being mobile and available on many occasions to represent the NSF across the country. Gender quotas reduce opportunities for men to engage in homosocial reproduction and hidden discrimination, but the recruitment logic does not change, remaining highly selective and producing new forms of inequality.

\section{Conclusion}

In recent years, the number of female candidates and board members in NSF governing bodies has been steadily growing. However, while gender diversity has increased, progress remains slow. The lack of female candidates may be partly to blame. Indeed, the quantitative results show that neither women nor men face voter bias. Women candidates are as successful as men when they run for office on executive boards. However, actors also develop strategies to weaken the impact of the law. Indeed, in investigating the electoral processes of an Olympic federation, we provide evidence that electoral competition is in fact limited, and that selection occurs before election day. Organisational resistance and endogenous mechanisms help to explain the lack of electoral competition and the shortfall of female applicants. The most interesting avenue for research appears to be further comparative investigations of informal pre-electoral negotiations. The election cycle that will occur after the Olympic games of Tokyo will provide some opportunities in this respect.

\section{Notes}

1. The Proportionality principle was the previous applicable law (see decree $n^{\circ} 2004-22,7$ January 2004). E.g.: if an NSF had $23 \%$ of women among its sports participants, it needed $23 \%$ of women in its governing bodies.

2. If the organisation's revenue is over 1 million euros, it can remunerate three of its board members (generally the chairperson, the secretary and the treasurer).

3. See www.sydneyscoreboard.com.

4. Schoch and Clausen (2019).

5. We do not mention the sport federation's name to ensure participant anonymity.

6. As allowed by the transition period.

7. The 'proportionality principle' was in force. See Decree $n^{\circ} 2004-22,7$ January 2004.

8. Sample of 27 Olympic federations from 36.

9. 2.2.2.2.3 Annexe I-5 art R131-1 et R131-11 of the Sport Code.

10. According to Ethics \& Boards, after the Copé-Zimmermann law, the share of women on SBF 120 company boards rose from $26 \%$ in 2013 to $43 \%$ in 2018. For more details, see http://www.ethicsandboards.com/publications/429instances-dirigeantes-ou-sont-les-femmes?lang=en.

\section{Disclosure statement}

No potential conflict of interest was reported by the authors. 


\section{References}

Adriaanse, J.A., 2019. Europe in world perspective: The Sydney Scoreboard Global Index for women in sport leadership. In: Gender Diversity in European Sport Governance. London: Routledge, 11- 19.

Ahern, K.R. and Dittmar, A.K., 2012. The changing of the boards : the impact on firm valuation of mandated female board representation. The quarterly journal of economics, 127 (1), 137-197. doi:10.1093/qje/qjr049

Bernardeau Moreau, D., 2004. Sociologie des fédérations sportives. La professionnalisation des dirigeants bénévoles. Paris: L'Harmattan.

Bower, G.G., 2009. Effective mentoring relationships with women in sport: results of a meta-ethnography. Advancing women in leadership, 29 (3), 1-21.

Chimot, C., 2005. Les dirigeantes dans les organisations sportives: le genre et le sport. Thesis (PhD). Université de Paris VIII, France.

Claringbould, I. and Knoppers, A., 2013. Understanding the lack of gender equity in leadership position in (sport) organizations. In: P. Leisink, et al., eds.. Managing social issues: A public values perspective, 162-179. Cheltenham: Edward Elgar Pub.

Claringbould, I. and Knoppers, A., 2007. Finding a 'normal'woman: selection processes for board membership. Sex roles, 56 (7-8), 495-507. doi:10.1007/s11199-007-9188-2

Claringbould, I. and Knoppers, A., 2012. Paradoxical practices of gender in sport-related organizations. Journal of sport management, 26 (5), 404-416. doi:10.1123/jsm.26.5.404

Cohen, J., 1992. A power primer. Psychological bulletin, 112 (1), 155.

Crozier, M., 1973. The problem of power. Social research, 40 (2), 211-228.

Crozier, M. and Friedberg, E., 1977. L'acteur et le système. Paris: Seuil.

Dahlerup, D. and Gaber, M.A., 2017. The legitimacy and effectiveness of gender quotas in politics in CE Europe. Teorija in Praksa, 54 (2), 307.

EIGE, 2015. Gender equality in power and decision-making. Brussel: European Institute for Gender Equality, Council of Europe.

Eliev, S. and Bernier, C., 2003. Perceptions de femmes cadres dans une entreprise typiquement masculine. Reflets: Revue ontaroise d'intervention sociale et communautaire, 9 (2), 87-113. doi:10.7202/011092ar

Elling, A., Knoppers, A., and Hovden, J., 2019. Data and methodologies. In: A. Elling, J. Hovden, and A. Knoppers, eds.. Gender diversity in European sport governance, 186-198. London: Routledge.

Enjolras, B. and Waldahl, R.H., 2010. Democratic governance and oligarchy in voluntary sport organizations: the case of the Norwegian olympic committee and confederation of sports. European sport management quarterly, 10 (2), 215-239. doi:10.1080/16184740903559909

Fox, R.L. and Lawless, J.L., 2004. Entering the Arena? Gender and the decision to run for office. American journal of political science, 48 (2), 264-280. doi:10.1111/j.0092-5853.2004.00069.x

Goffman, E., 1959. The presentation of self in everyday life. Garden City, New York: Doubleday and Anchor book.

Goffman, E., 2002. L'arrangement des sexes. Paris: La dispute.

Gresy, B., 2016. L'accès des femmes aux responsabilités dans les entreprises : un chemin semé d'embûches. Géoéconomie, 79 (2), 195-211. doi:10.3917/geoec.079.0195

Guichet, C., 2015. Les forces vives au féminin. Délégation aux droits des femmes et à l'égalité. Les éditions des journaux officiels, No. 32.

Hovden, J., 2000. 'Heavyweight' men and younger women? The gendering of selection processes in Norwegian sport organizations. NORA: Nordic journal of women's studies, 8 (1), 17-32.

Hovden, J., 2012. Discourses and strategies for the inclusion of women in sport-the case of Norway. Sport in society, 15 (3), 287-301. doi:10.1080/17430437.2012.653201

Hovden, J., Elling, A., and Knoppers, A., 2019. Policies and strategies. In: A. Elling, J. Hovden, and A. Knoppers, eds.. Gender diversity in European sport governance. London: Routledge.

Hoye, R. and Cuskelly, G., 2004. Board member selection, orientation and evaluation: implications for board performance in member-benefit voluntary sport organisations. Third sector review, 10 (1), 77.

International Federation of Assosiation Football. 2015. Federation Inspiring change FIFA Female leadership development programme. Zürich, Switzerland: International Federation of Assosiation Football.

International Olympic Committee, 2018. Gender equality review project. Lausanne: International Olympic Committee.

International Paralympic Committee, 2010. Women in sport leadership toolkit? Increasing opportunities for women in paralympic sport. Bonn, Germany: International Paralympic Committee.

Manin, B., 1997. The principles of representative government. Cambridge: Cambridge University Press.

Murray, R., Krook, M.L., and Opello, K.A., 2012. Why are gender quotas adopted? Party pragmatism and parity in France. Political research quarterly, 65 (3), 529-543. doi:10.1177/1065912911414590

Pfister, G. and Radtke, S., 2006. Dropping out: why male and female leaders in German sports federations break off their careers. Sport management review, 9 (2), 111-139. doi:10.1016/S1441-3523(06)70022-5

Piggott, L.V. and Pike, E.C., 2019. 'CEO equals man': gender and informal organisational practices in English sport governance. International review for the sociology of sport, 1-17. doi:10.1177/1012690219865980 
Rich, E., et al., 2004. Women, leadership and the olympic movement: research report to the international olympic committee. Loughborough: Loughborough University.

Schoch, L. and Clausen, J., 2019. Women within international sports federations: contemporary challenges. In: G. Cervin and C. Nicolas, eds. Histories of women's work in global sport: a man's world? Cham: Springer International Publishing, 299-326.

Sineau, M., 2012. Focus: système électoral, partis politiques et accès des femmes au Parlement. La France, terre d'exception en Europe. Etudes de la documentation française, 5359, 135-140.

Soler, S., Marta, M., and Vilanova, A., 2019. The voices of female chairs of sports clubs. In: A. Elling, J. Hovden, and A. Knoppers, eds.. Gender diversity in European sport governance, 63-74. London: Routledge.

Tatu-Colasseau, A. and Vieille Marchiset, G., 2010. Comment devient-on dirigeante d'une association sportive locale? Des processus de transmission à l'œuvre en lien avec les rapports sociaux de sexe. Staps, 90 (4), 75-92. doi:10.3917/ sta.090.0075

Troupel, A., 2013. Entre consolidation et remise en cause : les tribulations de la loi sur la parité depuis le 6 juin 2000. Modern \& contemporary France, 21 (1), 17-36. doi:10.1080/09639489.2012.719492

UEFA, 2018. The first UEFA-FIFA women in football leadership programme is under way, and is set to inspire a fresh cohort of female leaders [online]. UEFA. Available from: https://www.uefa.com/insideuefa/football-development/womensfootball/programme/news/newsid=2587014.html. [Accessed 28 December 2019]. 